Article

\title{
Low Temperature Illitization through Illite-Dioctahedral Vermiculite Mixed Layers in a Tropical Saline Lake Rich in Hydrothermal Fluids (Sochagota Lake, Colombia)
}

\author{
Gabriel Ricardo Cifuentes ${ }^{1}$, Juan Jiménez-Millán ${ }^{2, *}$, Claudia Patricia Quevedo ${ }^{1}$, Fernando Nieto ${ }^{3}$, \\ Javier Cuadros ${ }^{4}$ and Rosario Jiménez-Espinosa ${ }^{2}$ (1) \\ 1 Faculty of Science and Engineering, Campus Tunja, University of Boyacá, Tunja 15003, Colombia; \\ grcifuentes@uniboyaca.edu.co (G.R.C.); patriciaquevedo@uniboyaca.edu.co (C.P.Q.) \\ 2 Department of Geology and CEACTEMA, Campus Las Lagunillas, University of Jaén, 23071 Jaén, Spain; \\ respino@ujaen.es \\ 3 Department of Mineralogy and Petrology and IACT (CSIC-UGR), Faculty of Sciences, Campus Fuentenueva, \\ University of Granada, s/n, 18002 Granada, Spain; nieto@ugr.es \\ 4 Department of Earth Sciences, Natural History Museum, London SW7 5BD, UK; j.cuadros@nhm.ac.uk \\ * Correspondence: jmillan@ujaen.es
}

Citation: Cifuentes, G.R.;

Jiménez-Millán, J.; Quevedo, C.P.;

Nieto, F.; Cuadros, J.;

Jiménez-Espinosa, R. Low

Temperature Illitization through

Illite-Dioctahedral Vermiculite Mixed

Layers in a Tropical Saline Lake Rich

in Hydrothermal Fluids (Sochagota

Lake, Colombia). Minerals 2021, 11,

523. https://doi.org/10.3390/min 11050523

Academic Editors: Manuel Pozo Rodríguez and André Sampaio Mexias

Received: 15 April 2021

Accepted: 12 May 2021

Published: 15 May 2021

Publisher's Note: MDPI stays neutral with regard to jurisdictional claims in published maps and institutional affiliations.

Copyright: (c) 2021 by the authors. Licensee MDPI, Basel, Switzerland. This article is an open access article distributed under the terms and conditions of the Creative Commons Attribution (CC BY) license (https:// creativecommons.org/licenses/by/ $4.0 /)$
Abstract: In this investigation, we showed that high salinity promoted by hydrothermal inputs, reducing conditions of sediments with high content in organic matter, and the occurrence of an appropriate clay mineral precursor provide a suitable framework for low-temperature illitization processes. We studied the sedimentary illitization process that occurs in carbonaceous sediments from a lake with saline waters (Sochagota Lake, Colombia) located at a tropical latitude. Water isotopic composition suggests that high salinity was produced by hydrothermal contribution. Materials accumulated in the Sochagota Lake's southern entrance are organic matter-poor sediments that contain detrital kaolinite and quartz. On the other hand, materials formed at the central segment and near the lake exit (north portion) are enriched in organic matter and characterized by the crystallization of Fe-sulfides. X-ray diffraction (XRD), field emission scanning electron microscopy (FESEM), high resolution transmission electron microscopy (HRTEM), and energy dispersive X-ray spectrometry (EDX) data allowed for the identification of illite and illite-dioctahedral vermiculite mixed layers (I-DV), which are absent in the southern sediments. High humidity and temperate climate caused the formation of small-sized metastable intermediates of I-DV particles by the weathering of the source rocks in the Sochagota Lake Basin. These particles were deposited in the low-energy lake environments (middle and north part). The interaction of these sediments enriched in organic matter with the saline waters of the lake enriched in hydrothermal $\mathrm{K}$ caused a reducing environment that favored Fe mobilization processes and its incorporation to I-DV mixed layers that acted as mineral precursor for fast low temperature illitization, revealing that in geothermal areas clays in lakes favor a hydrothermal $\mathrm{K}$ uptake.

Keywords: Sochagota Lake; hydrothermal inputs; illite-dioctahedral vermiculite mixed layers; illitization

\section{Introduction}

There is increasing evidence that fast clay mineral reactions can act as important element sinks in sedimentary and diagenetic processes. Thus, different clay mineral transformations have been proposed to lead to long-term sequestration of elements (such as K or $\mathrm{Fe}$ ) in sedimentary, diagenetic, and hydrothermal settings [1,2]. Time and temperature are the most important variables that control the mineral phases formed by burial diagenesis. Extended time lapses combined with temperature increases are commonly required for the crystallization of diagenetic minerals. However, reactive clay surfaces can influence adsorption-desorption processes. The presence of high concentrations of elements able to 
be included in the clay structure affects the reaction rates, promoting an increase of clay transformation speed [3]. In sedimentary and diagenetic systems, clay reactions can be influenced by elevated water salinity and oxygen-depleted conditions that favor reducing transformations (e.g., of Fe) mediated by microorganisms [4-6]. High concentration of cations and biological activity are frequently due to specific sediment composition, hydrology, and climatic conditions, such as those that can be generated in saline lakes or mangrove soils [6-9]. In these environments with hydrologically restricted conditions, clays of detrital origin interact with high salinity waters, producing phase authigenesis. Singer and Stoffers [10] revealed that K-enriched paleo-lake waters produced the diagenetic transformation of smectite into illite in two East African lakes. Deconinck et al. [11,12] also evidenced syndepositional smectite illitization in Purbeckian sediments under hypersaline conditions. Eberl et al. [13] suggested that cycles of wetting and drying cycles can be involved in the formation mechanism of illite.

The effect of high salinity waters on clays favors the modification of the octahedral layer charge (through Fe reduction and $\mathrm{Fe}-\mathrm{Mg}$ for $\mathrm{Al}$ substitution), producing the transformation of smectite to illite [14]. Deocampo [7] suggested that the interaction of clays with K-rich waters can yield sedimentary illitization. In this paper, we study the illite formation process in the Sochagota Lake (Paipa Colombia), a saline lake located in a geothermal area [15].

In lakes from geothermal regions, the chemical evolution of the waters can be influenced by hydrothermal inputs. Metals can be included in the geothermal systems from a magmatic source and/or through dissolution of rocks processes (e.g., [16-19]). In volcanic areas, fluid-rock (basaltic or rhyolitic) reactions play an important control on the composition of the hydrothermal waters. When the rocks are predominantly rhyolitic, such as those of the Paipa volcano [20], the fluid chemical composition is mainly controlled by water-rock interaction [21], producing high concentrations of alkaline elements. A later discharge into rivers and lakes causes hydrothermally-modified waters that further react with detrital minerals, which may result in singular sediment mineralogies.

Many mineral reactions at low temperature are not controlled by thermodynamics but kinetics. Clay transformations such as the illitization process require not only sufficient reaction time or cation availability but also an appropriate mineral precursor. Smectite or illite-smectite mixed layers are the most frequently proposed clay precursors for illite formation in sedimentary basins (e.g., [22]), paleosoils (e.g., [9]), and mangrove soils (e.g., [8]). However, Dietel et al. [23] observed that the transformation to illite can also be produced through illite-dioctahedral vermiculite (I-DV) interstratification.

This investigation characterizes the mineralogical changes taking place in the clays from the Sochagota Lake sediments (Colombia). The detrital sediments are kaolinite-rich. The waters are low-temperature and saline fluids with a hydrothermal input. The climate is tropical to temperate, which allows for large organic matter accumulation in the sediments. The aim of this study is to clarify whether I-DV could act as a mineral precursor in a fast low-temperature illitization and to provide evidence of the relevant effect of clays on the hydrothermal $\mathrm{K}$ uptake in lakes from geothermal areas.

\section{Geological Context}

We studied sediments from the Sochagota Lake, which is situated in the province of Paipa at the Boyacá region (Colombia) (Figure 1). This lake has an extension of $1.7 \mathrm{~km}^{2}$. A deepest point of $3.15 \mathrm{~m}$ can be observed. This lake is fed by the Salitre River from the south entrance and forms a small artificial basin by the effect of a dam constructed at the north border of the lake. The Sochagota Lake accumulates saline waters of hydrothermal origin [24]. These waters are periodically discharged through the north exit of the dam into the Chicamocha River (flowing from east to west), in which basin the Sochagota Lake is included (Figure 2) [25,26]. The climate of the area can be classified as Cfb by the Köppen system, corresponding to a climate of subtropical highland (height, $2496 \mathrm{~m}$ ) under oceanic 
conditions. The average temperature of the Sochagota Lake region is around $15{ }^{\circ} \mathrm{C}$, and the rainfall is around $900 \mathrm{~mm} / \mathrm{y}$.

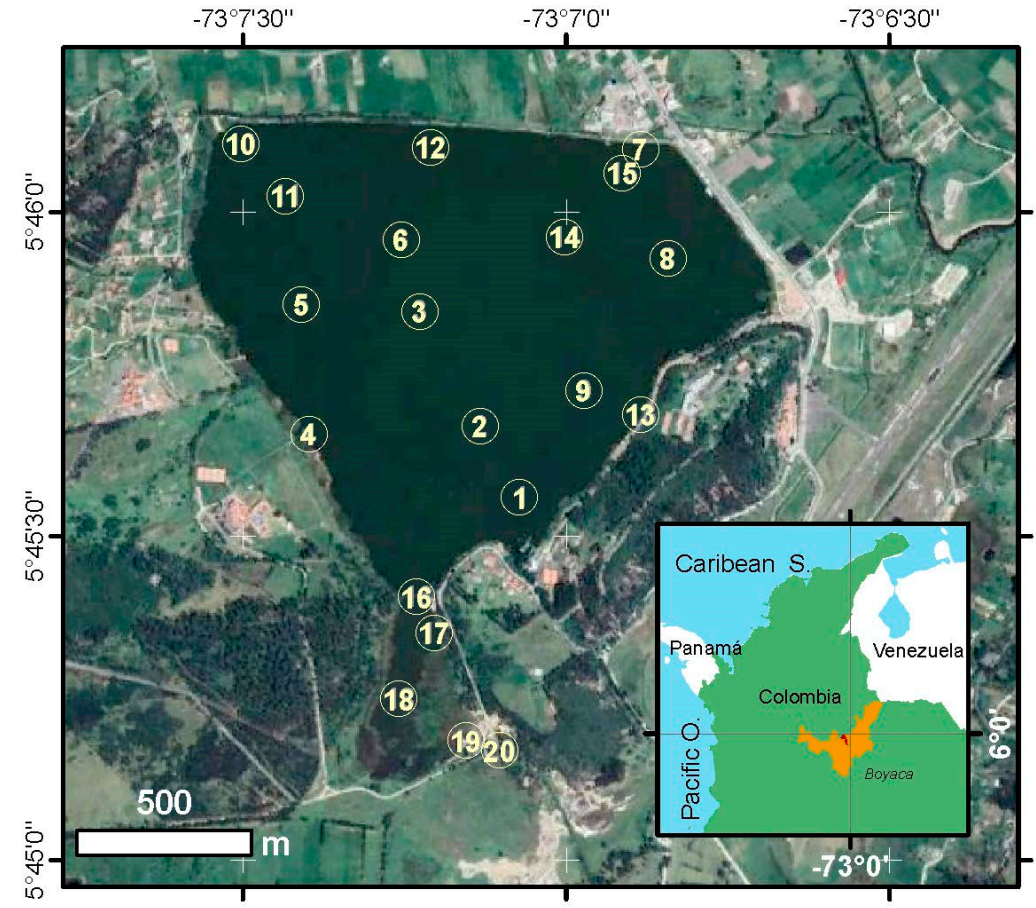

Figure 1. Location of the study region and sample positions (numbers 1 to 20) in the Sochagota Lake. The small map represents the regional context of the global area, i.e., situation of the Paipa province (Boyaca region) in Colombia. Modified from [25].

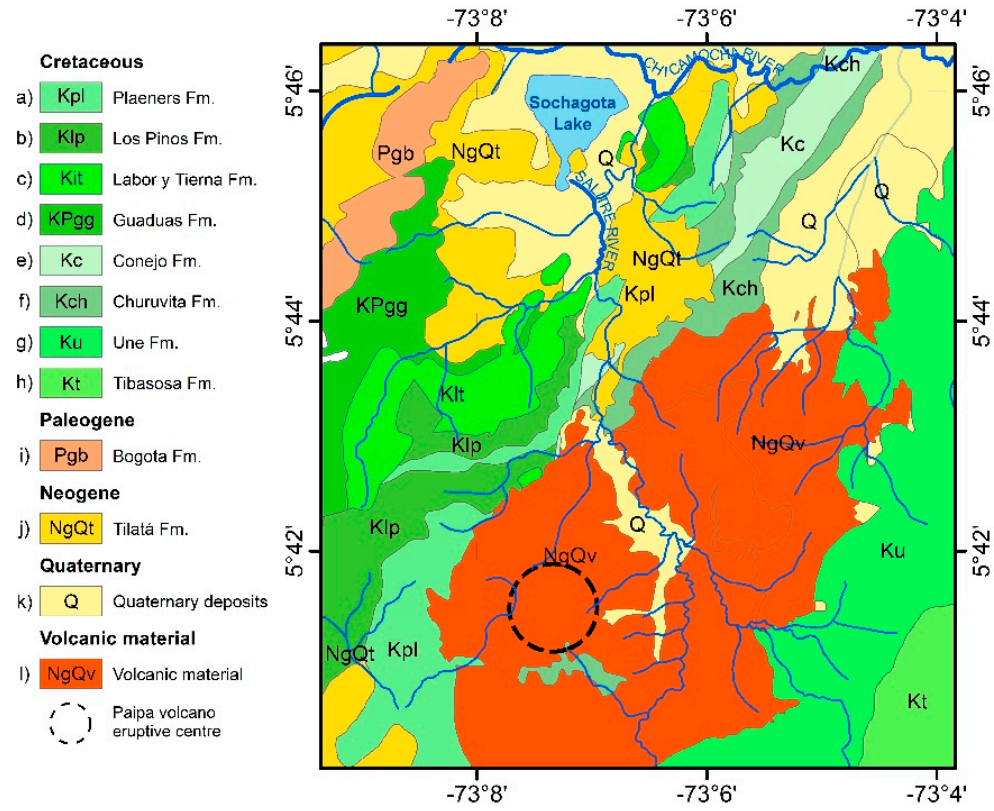

Figure 2. The Sochagota Lake Basin. Modified from [15].

From the geological perspective, the Sochagota Lake belongs to an important geothermal area that develops hydrothermal systems associated to volcanoes of the Andean Cordillera intruding cretaceous sediments rich in silicates (Figure 2). The most important outcrops as a source of sediments to the lake are rocks from the following formations: 
(a) Plaeners Formation (Cretaceous), made of intensely deformed radiolarites; (b) Los Pinos Formation (Cretaceous), formed by siltstones and quartz sandstone beds; (c) Labor-Tierna Formation (Cretaceous), made of coarse to fine-grained quartz sandstones; (d) Guaduas Formation (Maastrichtian-Paleocene), with clays and siltstones that include abundant intercalations of quartz sandstones; other siliceous cretaceous formations such as (e) Conejo Formation, (f) Churuvita Formation, (g) Une Formation, and (h) Tibasosa Formation; (i) Bogotá Formation (Late Paleocene-Early Eocene), consisting of quartz sandstones, siltstones and clays; (j) Tilatá Formation (Pliocene-Pleistocene) that discordantly overlies the Cretaceous and Paleogene materials and is predominantly made of quartz-rich sandy levels with beds of siltstones and clays; (k) Quaternary deposits of sands, silts, clays, and conglomerates overlying the Tilatá Formation corresponding to the most recent alluvial, lacustrine, and fluvio-lacustrine activity also deposited in the Chicamocha River Basin, mainly made of kaolinite and quartz $[25,26]$. The southern part of the Sochagota Lake basin is occupied by the Pliocene-Pleistocene acid pyroclastic deposits of the Paipa volcano (1 in Figure 2) [20]. This volcanic building is characterized by the presence of a collapsed caldera that includes hydrothermal vents associated to deep faults discharging $\mathrm{SO}_{4}-\mathrm{Na}-\mathrm{K}$-rich thermal waters and Fe-rich cold waters [27]. These hydrothermal saline waters mixed with rain waters flow from $N$ to $S$ through the Salitre River to feed the Sochagota Lake $[24,27,28]$.

\section{The Waters and Sediments of the Lake}

Natural hydrothermal saline waters feed the Sochagota Lake at the south entrance from El Salitre River [27]. These hydrothermal waters are mixed at the lake with rain surface waters, causing waters to be rich in $\mathrm{SO}_{4}{ }^{2-}$ (around $2150 \mathrm{mg} / \mathrm{L}$ ), $\mathrm{Na}^{+}$(around $1500 \mathrm{mg} / \mathrm{L}$ ), and $\mathrm{K}^{+}$(around $280 \mathrm{mg} / \mathrm{L}$ ) $[27,28]$. The waters of the lake are alkaline (pH around 9.3) and show very high electric conductivity (around $2500 \mu \mathrm{S} / \mathrm{cm}$ ). Cifuentes et al. [27,28] suggested that the mean values of $\delta^{34} \mathrm{~S}(6.4 \% \mathrm{~s})$ and $\delta^{18} \mathrm{O}(8.1 \% \mathrm{\%})$ reveal an isotopic composition of the water analogous to other hydrothermal waters (see e.g., [29,30]). Considering these data and that evaporitic rocks are absent in the geological framework, Cifuentes et al. [27] argued that hydrothermal inputs are responsible of the S-enrichment of the waters and its high salinity.

Cifuentes et al. [28] documented an important variation in the geochemical distribution of sediments in the Sochagota Lake. Sediments near the south entrance have high contents of some elements commonly considered as detrital ( $\mathrm{Zr}, \mathrm{Si}, \mathrm{Al}$, Ti, and $\mathrm{Na}$ ) and show low organic-matter contents (Total Organic Carbon, TOC $<0.7$ wt. $\%$ ). Cifuentes et al. $[27,28]$ indicated that the deposit of this type of materials is related to the prevalence of transport conditions over the deposit of particles due to the higher hydraulic energy of the waters at this segment of the lake. The deposit of clay-rich sediments with high contents of organic matter (values of TOC around $11 \mathrm{wt} . \%$ ) is characteristic of the deepest sections of the lake (located at the center and north parts). These sediments have Eh (redox potential) near $-150 \mathrm{mV}$ and high contents in $\mathrm{S}$ and metal transition elements. Cifuentes et al. $[27,28]$ also showed that these materials contain Fe sulfide nanoparticles enriched in heavy metals caused by sulfate reducing bacteria (SRB) activity.

The 20 points of sediment sampling in the lake are shown Figure 1. Cores up to $0.5 \mathrm{~m}$ deep were collected using a standard stainless Shelby tube. Sediments from the entrance of the lake (south segment) have light colors and a sandy aspect. Samples near the lake exit (at the deepest parts located at the center and north) are dark, rich in very fine grain fractions, and have a great amount of plant remains.

\section{Methods}

The drying of sediments was carried out at $45^{\circ} \mathrm{C}$ for $72 \mathrm{~h}$. Samples were ground, and then the silt and clay fractions were separated and washed (eliminating salts) by wet sieving. After successive washing with deionized water, the $<0.2 \mu \mathrm{m}$ fraction was separated from the existing $<2 \mu \mathrm{m}$ fraction by consecutive cycles of centrifugation (10 to 15 times, at $4200 \mathrm{rpm}$ for $20 \mathrm{~min}$ ). 
We obtained X-ray diffraction (XRD) diagrams from random powders and oriented the aggregates from the whole sample and from the $<2 \mu \mathrm{m}$ and $<0.2 \mu \mathrm{m}$ fractions. A dispersion on a glass slide was used to make the oriented aggregates, which were treated in several ways to identify expandable minerals. They were analyzed as air-dried, intercalated with ethylene glycol (obtained in saturated environment at $60^{\circ} \mathrm{C}$ for $24 \mathrm{~h}$ ), intercalated with glycerol (obtained in a saturated environment at $40^{\circ} \mathrm{C}$ for $24 \mathrm{~h}$ ), and heated at $300{ }^{\circ} \mathrm{C}$ during $1 \mathrm{~h}$. The diffraction patterns were obtained with a PANalytical $\mathrm{X}^{\prime}$ Pert Pro diffractometer ( $\mathrm{CuK} \alpha$ radiation, $45 \mathrm{kV}, 40 \mathrm{~mA}$ ) equipped with an automatic slit and an $\mathrm{X}^{\prime}$ Celerator solidstate linear detector (University of Jaén, Spain). This detector continuously scans and integrates the diffracted intensity in an arc of $2.1^{\circ} 2 \theta$. The conditions used were equivalent to a $0.008^{\circ} 2 \theta$ step increment and a $10 \mathrm{~s} /$ step counting time. Random powders as well as air-dried oriented mounts were scanned from 3 to $65^{\circ} 2 \theta$, while all other samples were scanned from 2 to $30^{\circ} 2 \theta$ to identify expandable minerals.

A field emission scanning electron microscope (FESEM, Merlin Carl Zeiss, University of Jaén) was used for textural and chemical observations. Polished sections of sediments previously consolidated with a polyester resin were studied with backscattered electrons (BSE). Secondary electron (SE) mode of unconsolidated sediment fragments were also used for obtaining topographical images. Chemical analyses of minerals were obtained with an Oxford Inca energy dispersive X-ray spectrometry (EDX) system.

A high resolution transmission electron microscopy (HRTEM) study of the nanometric textural and compositional features was carried out on finely powdered samples. Selected samples (according to the XRD and FESEM results) were finely ground and dispersed in distilled water. After settling dispersion for some minutes to allow the coarser particles to settle, a drop was deposited on $\mathrm{Au}$ or $\mathrm{Cu}$ grids coated with formvar resin. We used two microscopes from the University of Granada: the HAADF FEI Titan G2 microscope, operated at $300 \mathrm{kV}$, and the Philips CM20 microscope, operated at $200 \mathrm{kV}$. Quantitative analyses of particles were acquired in scanning transmission mode (STEM) with an EDX microanalysis system. A 100-s counting time was used, excluding $\mathrm{Na}$ and $\mathrm{K}$, for which $15 \mathrm{~s}$ of analysis were used to minimize alkali-loss and improve $\mathrm{K}$ and $\mathrm{Na}$ determinations [31].

\section{Results}

\subsection{XRD Data}

XRD patterns of random powders and oriented aggregates from the $<2 \mu \mathrm{m}$ and 0.2 size fractions are shown in Figure 3 (samples from the southern part of the lake) and Figure 4 (samples from the deepest parts at the center and northern part of the lake).

Quartz and kaolinite are the dominant phases in the southern sediments. The presence of kaolinite was documented by intense and sharp $7.18 \AA$ and $3.57 \AA$ reflections of the $<2 \mu \mathrm{m}$ and $<0.2 \mu \mathrm{m}$ fractions patterns (Figure $3 \mathrm{~b}, \mathrm{c}$ ). These peaks do not vary after ethylene glycol treatment, indicating kaolinite-smectite mixed-layer minerals (K-S) were absent.

Random powders patterns from the central and northern sediments show a more intense peak of phyllosilicates at $4.47 \AA$ and a broad peak of low intensity around $10.20 \AA$ (Figure 4a). Oriented air-dried aggregates from the $<2 \mu \mathrm{m}$ fraction are characterized by a broad and asymmetric peak with an abrupt side at $10 \AA$ (Figure $4 \mathrm{~b}$ ). Ethylene glycol treatment produces a more symmetric peak at $10 \AA$, and the presence of a zone of slightly higher intensities around $16.50 \AA \mathrm{d}$-spacings (Figure $4 \mathrm{~b}$ ). The abrupt right edge of the $10 \AA$ peak and the $3.33 \AA$ peak (which interferes with the $3.34 \AA$ reflection of quartz) in the air-dried pattern and the $10 \AA$ symmetric peak in the ethylene glycol pattern (Figure $4 \mathrm{~b}$ ) were interpreted as due to the presence of illite in the $<2 \mu \mathrm{m}$ fraction. 


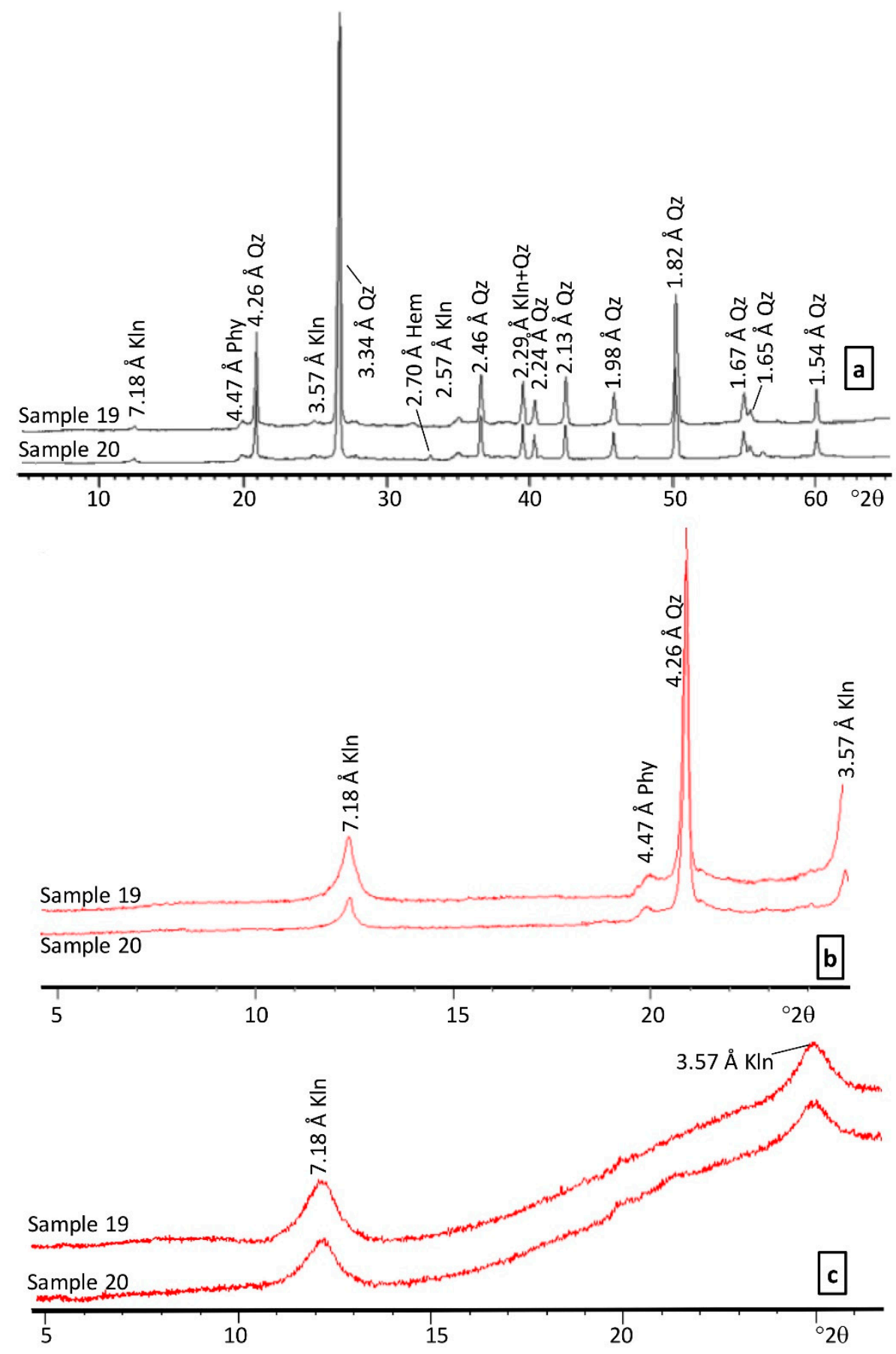

Figure 3. Representative XRD diagrams of samples from the southern entrance of the Sochagota Lake. (a) Whole random powders. (b) Air-dried oriented aggregates of the $<2 \mu \mathrm{m}$ size fraction; XRD diagrams of the ethylene glycol treated samples completely overlap the air-dried diagrams. (c) Airdried oriented aggregates of the $<0.2 \mu \mathrm{m}$ size fraction; XRD diagrams of the ethylene glycol treated samples completely overlap the air-dried diagrams. Phy: phyllosilicates, Kln: kaolinite, Qz: quartz. 

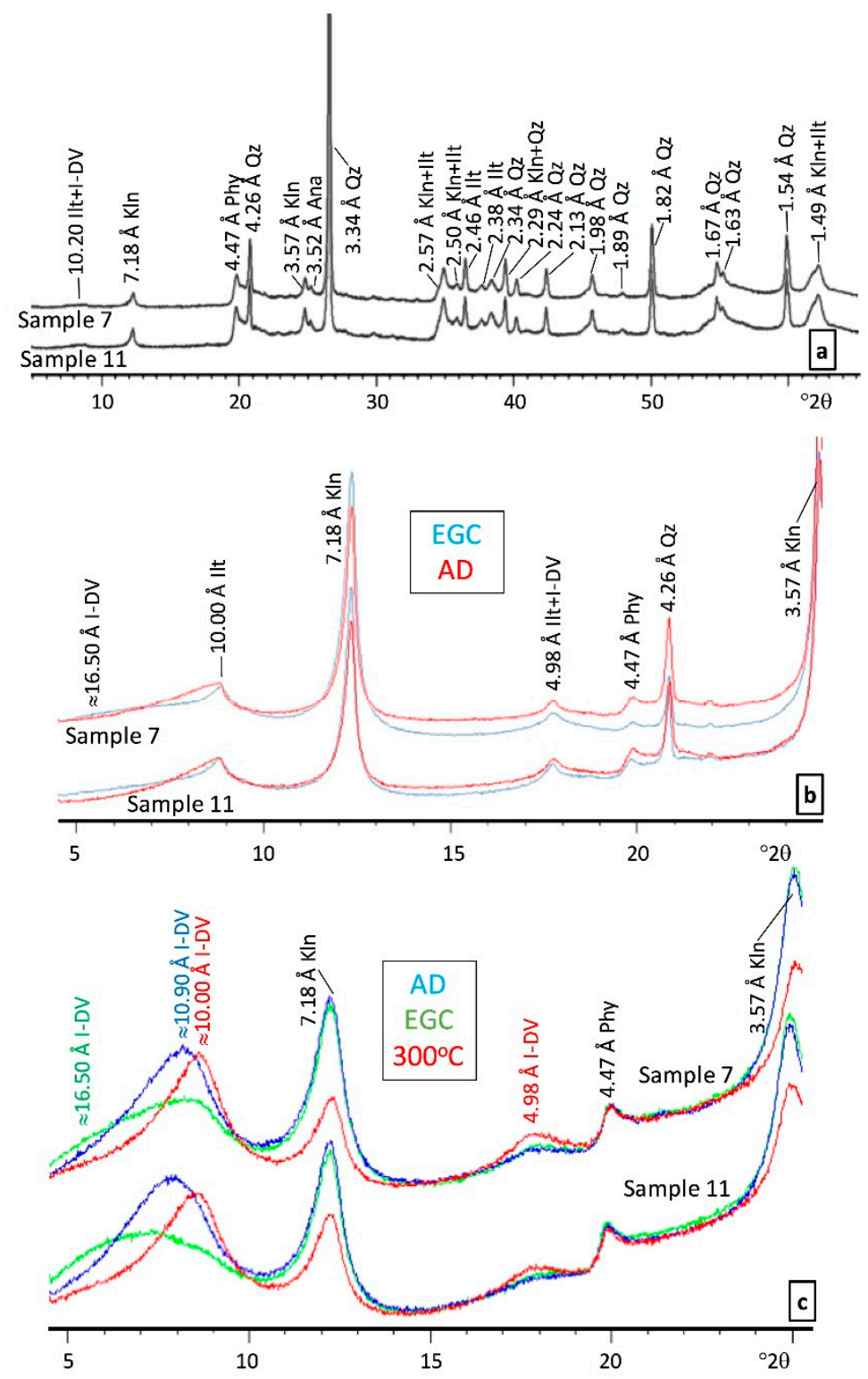

Figure 4. Representative XRD diagrams of samples from the central and northern parts of the Sochagota Lake. (a) Whole random powders. (b) Oriented aggregates of the $<2 \mu \mathrm{m}$ size fraction. (c) Oriented aggregates of the $<0.2 \mu \mathrm{m}$ size fraction. AD: air-dried samples. EGC: samples treated with ethylene-glycol. $300{ }^{\circ} \mathrm{C}$ : samples heated to $300{ }^{\circ} \mathrm{C}$. Kln: kaolinite, I-DV: illite-dioctahedral vermiculite mixed layers, Ilt: illite, Qz: quartz.

To characterize the nature of the phases that form the broad peak around $16.50 \AA$ in the ethylene glycol pattern of the $<2 \mu \mathrm{m}$ fraction, a detailed study of the $<0.2 \AA$ size fraction was carried out (Figure 4c). In this size fraction, the intensity of the kaolinite peaks decreases, and the $10 \AA$ peak of illite was not observed in the air-dried patterns. However, a broad peak around $10.9 \AA$ was identified, suggesting the presence of mixed layers. After ethylene glycol treatment, this peak decreases its intensity, and although part of the peak slightly changes its position toward higher d-spacings, the characteristic peak of the smectitic phases around $17 \AA$ was not observed. The peak collapses to $10 \AA$ after heating to $300{ }^{\circ} \mathrm{C}$. On the other hand, the peak does not change after glycerol treatment, which ruled out a smectitic nature of the expansible component of the mixed layer. Therefore, the partial swelling character with ethylene glycol and the collapse after $300{ }^{\circ} \mathrm{C}$ of the mixed layer need to be explained by a vermiculitic component [32]. The chemical data obtained 
in TEM (see below) show that this vermiculitic component is dioctahedral, and hence I-DV are present in the sediments from central and northern lake segments.

This I-DV mineral is rich in illite layers ( $85-90 \%$ illite layers) as indicated by the intensity and minor modifications of the peak at $\approx 10 \AA$ in the ethylene glycol samples and also by the lack of a peak at $\approx 17 \AA$ in the same samples. According to the relative peak intensities, the I-DV mineral phase can be up to $50 \%$ of the $<0.2 \mathrm{um}$ fraction.

In summary, several facts can be highlighted from the above results. Sediments highly rich in kaolinite are located in the southern part of the lake where illite is absent. In the sediments from the north part of the lake, I-DV and illite are abundant in the $<2$ and $<0.2 \mu \mathrm{m}$ fractions.

\subsection{SEM-EDX Data}

The light colored and compact sediments deposited at the south lake entrance are characterized in the scanning electron microscope images by the presence of large crystals of quartz (from 100 to $800 \mu \mathrm{m}$, Figure 5a) included in a phyllosilicate matrix rich in small flakes of subhexagonal kaolinite (Figure 5b). Small amounts of $\mathrm{K}$ and Fe in the EDX spectra of kaolinite can be associated to the adsorption of these elements from the interstitial waters of the sediments of hydrothermal origin. Sediment micropores are cemented by microcrystal aggregates of calcite (Figure 5c).
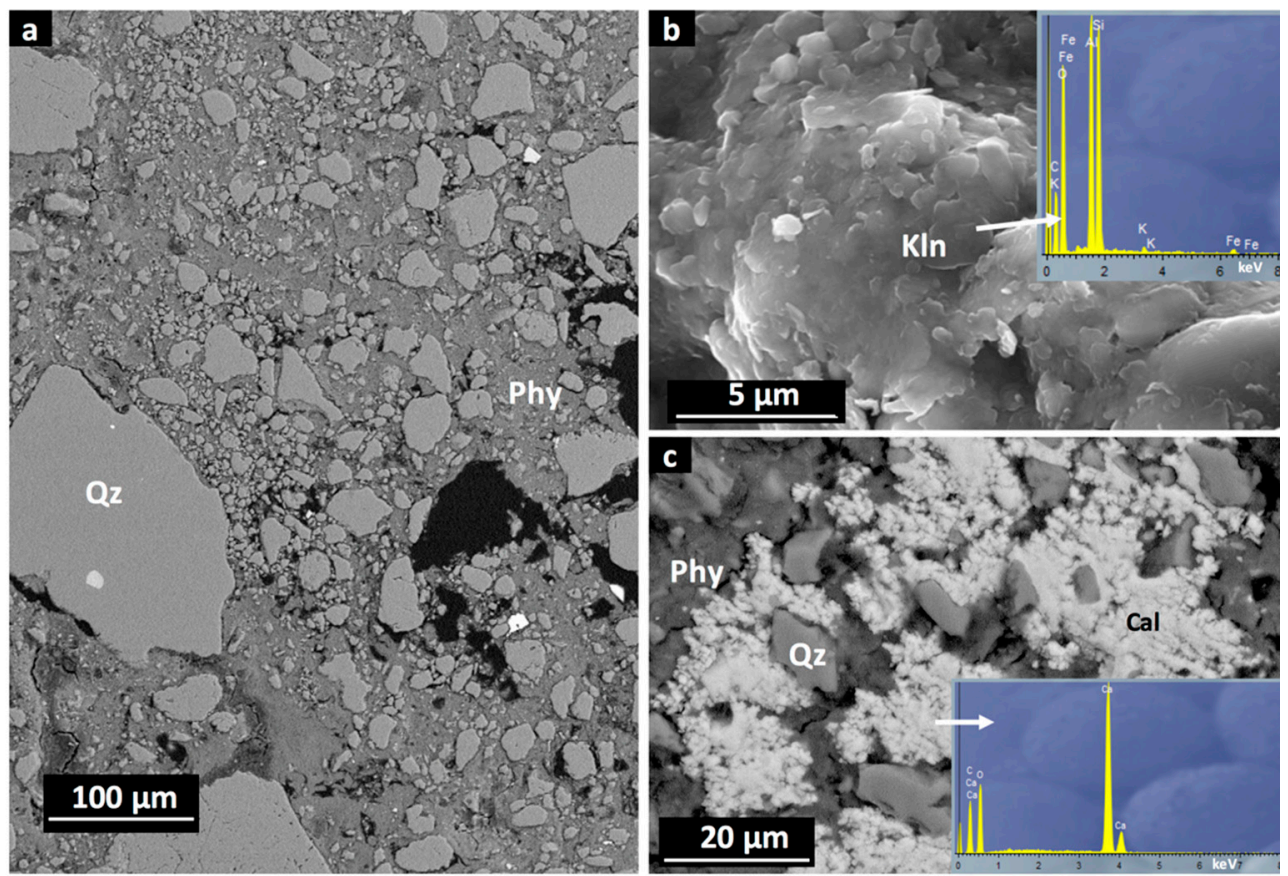

Figure 5. FESEM images of samples from the southern entrance of the lake. (a) BSE image of grains of quartz in a phyllosilicate matrix; (b) SE image of kaolinite aggregate crystals. (c) BSE image of calcite filling sediment micropores. Phy: phyllosilicates, Kln: kaolinite, Qz: quartz, Cal: calcite.

The clay-rich matrix is predominant in the very fine grain sized sediments from the central and northern areas (Figure 6a). The sediment matrix commonly contains long plant fragments of up to $60 \mu \mathrm{m}$ of diameter (Figure 6a). The SEM images show that clay aggregates of massive aspect are frequent with EDX analyses, indicating the presence of $\mathrm{K}$, $\mathrm{Fe}$, and a higher $\mathrm{Si} / \mathrm{Al}$ ratio than in kaolinite (Figure $6 \mathrm{~b}$ ). Pyrite framboids are frequently found in these areas (Figure 6a,c). 

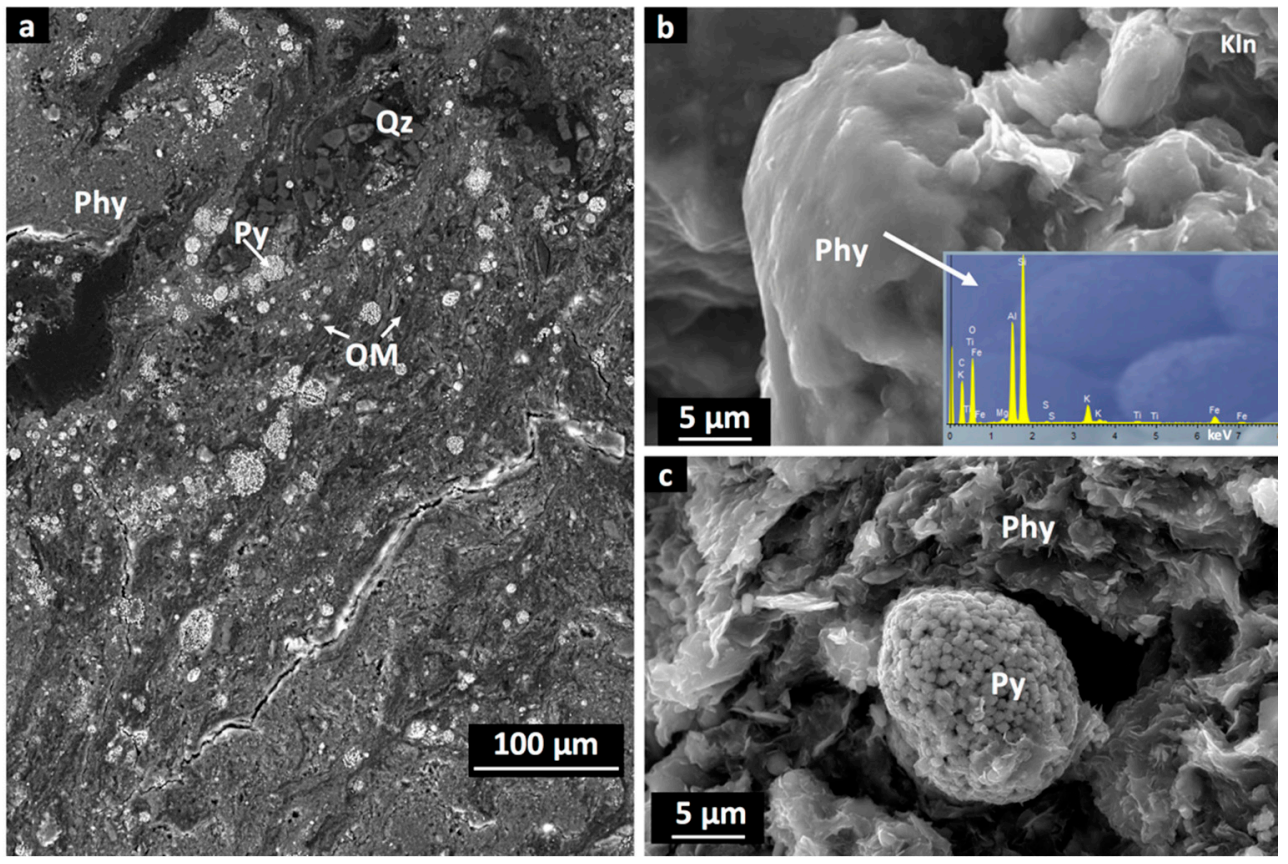

Figure 6. FESEM images of lake samples from the central and northern parts. (a) Elongated areas rich in organic matter (plant remains) and sulfide framboids included in a matrix rich in clay-minerals (BSE image); (b) SE picture showing massive clay aggregates in which EDX analyses indicate the presence of $\mathrm{K}, \mathrm{Fe}$, and a higher $\mathrm{Si} / \mathrm{Al}$ ratio than in kaolinite. (c) SE image of a framboid of pyrite. Phy: phyllosilicates, Qz: quartz, OM: organic matter, Py: pyrite.

\subsection{HRTEM-EDX Data}

According to the grain morphology, the composition, and lattice fringe images, three groups of clays can be identified through the HRTEM-EDX study of the Sochagota Lake sediments. Selected compositions of these minerals are shown in Table 1.

Table 1. HRTEM-EDX chemical analyses. I-DV and illite standardized to $\mathrm{O}_{10}(\mathrm{OH})_{2}$. Kaolinite standardized to $\mathrm{O}_{10}(\mathrm{OH})_{8}$. ${ }^{\mathrm{IV}} \mathrm{Al}=(4-\mathrm{Si})$.

\begin{tabular}{|c|c|c|c|c|c|c|c|c|c|c|}
\hline $\begin{array}{l}\text { Sample- } \\
\text { Analysis }\end{array}$ & Si & $\mathrm{Al}^{\mathrm{IV}}$ & $\mathrm{Al}^{\mathrm{VI}}$ & Fe & $\mathrm{Mg}$ & $\sum^{\mathbf{V I}}$ & $\mathrm{Ca}$ & $\mathbf{K}$ & $\mathrm{Na}$ & $\sum^{\mathrm{XII}}$ \\
\hline \multicolumn{11}{|c|}{ Illite-dioctahedral vermiculite mixed layers (I-DV) } \\
\hline $7-1$ & 3.50 & 0.50 & 1.75 & 0.12 & 0.10 & 1.97 & 0.04 & 0.60 & 0.01 & 0.65 \\
\hline $7-2$ & 3.35 & 0.65 & 1.80 & 0.15 & 0.05 & 2.00 & 0.04 & 0.62 & 0.00 & 0.66 \\
\hline $7-3$ & 3.40 & 0.60 & 1.72 & 0.16 & 0.12 & 2.00 & 0.03 & 0.64 & 0.02 & 0.69 \\
\hline $7-4$ & 3.43 & 0.57 & 1.79 & 0.13 & 0.05 & 1.97 & 0.05 & 0.60 & 0.01 & 0.66 \\
\hline $7-5$ & 3.38 & 0.62 & 1.73 & 0.16 & 0.13 & 2.02 & 0.04 & 0.58 & 0.03 & 0.65 \\
\hline $8-1$ & 3.48 & 0.52 & 1.78 & 0.11 & 0.10 & 1.99 & 0.03 & 0.58 & 0.01 & 0.62 \\
\hline $8-2$ & 3.36 & 0.64 & 1.72 & 0.16 & 0.14 & 2.02 & 0.05 & 0.61 & 0.01 & 0.67 \\
\hline $8-3$ & 3.47 & 0.53 & 1.75 & 0.15 & 0.08 & 1.98 & 0.05 & 0.56 & 0.01 & 0.62 \\
\hline $8-4$ & 3.37 & 0.63 & 1.70 & 0.18 & 0.14 & 2.02 & 0.05 & 0.60 & 0.01 & 0.66 \\
\hline $8-5$ & 3.42 & 0.58 & 1.74 & 0.12 & 0.15 & 2.01 & 0.04 & 0.60 & 0.02 & 0.66 \\
\hline $8-6$ & 3.39 & 0.61 & 1.73 & 0.15 & 0.12 & 2.00 & 0.03 & 0.63 & 0.03 & 0.69 \\
\hline $11-1$ & 3.36 & 0.64 & 1.71 & 0.15 & 0.14 & 2.00 & 0.05 & 0.61 & 0.01 & 0.67 \\
\hline $11-2$ & 3.36 & 0.64 & 1.89 & 0.12 & 0.05 & 2.06 & 0.03 & 0.62 & 0.02 & 0.67 \\
\hline $11-3$ & 3.46 & 0.54 & 1.77 & 0.15 & 0.09 & 2.01 & 0.05 & 0.56 & 0.01 & 0.62 \\
\hline $11-4$ & 3.44 & 0.56 & 1.81 & 0.12 & 0.05 & 1.98 & 0.04 & 0.61 & 0.02 & 0.67 \\
\hline $13-1$ & 3.37 & 0.63 & 1.71 & 0.17 & 0.13 & 2.01 & 0.04 & 0.58 & 0.03 & 0.65 \\
\hline $13-2$ & 3.49 & 0.51 & 1.79 & 0.12 & 0.10 & 2.01 & 0.02 & 0.59 & 0.02 & 0.63 \\
\hline $13-3$ & 3.41 & 0.49 & 1.73 & 0.12 & 0.13 & 1.98 & 0.04 & 0.61 & 0.01 & 0.66 \\
\hline $13-4$ & 3.38 & 0.62 & 1.71 & 0.18 & 0.12 & 2.01 & 0.05 & 0.60 & 0.01 & 0.66 \\
\hline $13-5$ & 3.49 & 0.51 & 1.76 & 0.12 & 0.11 & 1.99 & 0.04 & 0.60 & 0.01 & 0.65 \\
\hline
\end{tabular}


Table 1. Cont.

\begin{tabular}{|c|c|c|c|c|c|c|c|c|c|c|}
\hline $\begin{array}{l}\text { Sample- } \\
\text { Analysis }\end{array}$ & Si & $\mathrm{Al}^{\mathrm{IV}}$ & Al VI & $\mathrm{Fe}$ & $\mathrm{Mg}$ & $\sum^{\mathbf{V I}}$ & $\mathrm{Ca}$ & $\mathbf{K}$ & $\mathrm{Na}$ & $\sum^{\mathrm{XII}}$ \\
\hline \multicolumn{11}{|c|}{ Illite } \\
\hline $7-1$ & 3.36 & 0.64 & 1.59 & 0.31 & 0.1 & 2.00 & 0.00 & 0.68 & 0.06 & 0.74 \\
\hline $7-2$ & 3.30 & 0.7 & 1.57 & 0.29 & 0.16 & 2.02 & 0.03 & 0.7 & 0.04 & 0.77 \\
\hline $7-3$ & 3.33 & 0.67 & 1.55 & 0.32 & 0.14 & 2.01 & 0.02 & 0.7 & 0.04 & 0.76 \\
\hline $8-1$ & 3.39 & 0.61 & 1.62 & 0.24 & 0.12 & 1.98 & 0.01 & 0.71 & 0.03 & 0.75 \\
\hline $8-2$ & 3.37 & 0.63 & 1.58 & 0.3 & 0.12 & 2.00 & 0.01 & 0.71 & 0.03 & 0.75 \\
\hline $11-1$ & 3.32 & 0.68 & 1.56 & 0.3 & 0.15 & 2.01 & 0.03 & 0.69 & 0.03 & 0.75 \\
\hline $11-2$ & 3.34 & 0.66 & 1.56 & 0.31 & 0.14 & 2.01 & 0.02 & 0.69 & 0.05 & 0.76 \\
\hline $13-1$ & 3.38 & 0.62 & 1.62 & 0.25 & 0.11 & 1.98 & 0.01 & 0.7 & 0.02 & 0.73 \\
\hline \multicolumn{11}{|c|}{ Kaolinite } \\
\hline $11-1$ & 4.03 & 0.00 & 3.87 & 0.09 & 0.00 & 3.96 & - & - & - & - \\
\hline $11-2$ & 4.00 & 0.00 & 3.94 & 0.05 & 0.00 & 3.99 & - & - & - & - \\
\hline $19-1$ & 4.01 & 0.00 & 3.91 & 0.07 & 0.00 & 3.98 & - & - & - & - \\
\hline $20-1$ & 4.02 & 0.00 & 3.92 & 0.08 & 0.00 & 4.00 & - & - & - & - \\
\hline $20-2$ & 4.01 & 0.00 & 3.93 & 0.07 & 0.00 & 4.00 & - & - & - & - \\
\hline
\end{tabular}

Note: $\mathrm{Al}^{\mathrm{IV}}$ : tetrahedral $\mathrm{Al} ; \mathrm{Al}^{\mathrm{VI}}$ : octahedral $\mathrm{Al} ; \sum^{\mathrm{VI}}$ : total octahedral cations; $\sum^{\mathrm{XII}}$ : total interlayer cations.

Kaolinite pseudohexagonal crystals are predominant in the sediments from the south entrance of the lake, although irregular crystals can also be observed with quartz grains in the sediment matrix (Figure 7). However, the chemical compositions are very similar in both types of grains (Table 1). Interlayer cations $(\mathrm{K}, \mathrm{Ca}$, and $\mathrm{Na}$ ) are almost absent. Kaolinite composition displays low values of iron in all analyzed grains ( $<0.1$ atoms p.f.u.), and magnesium was not detected.
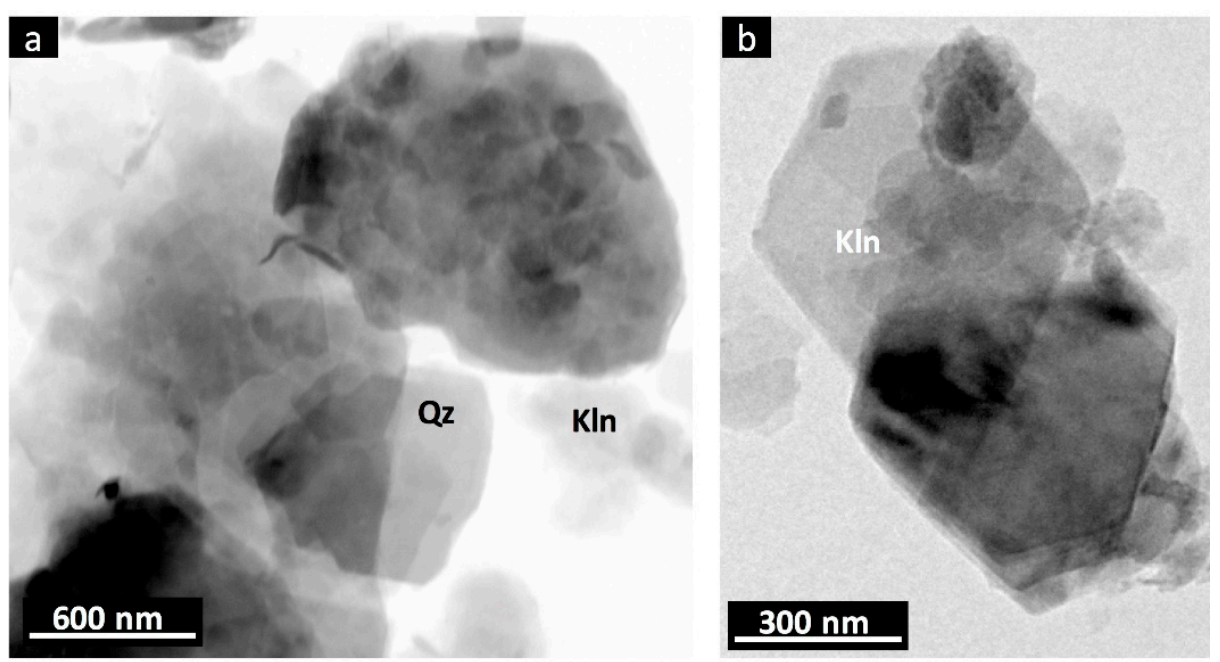

Figure 7. HRTEM pictures of sediments from the lake's southern entrance. (a) Low-magnification image displaying an aggregate of quartz and kaolinite. (b) Detail of pseudohexagonal crystals of kaolinite. Kln: kaolinite, Qz: quartz.

Lake sediments from the center and the northern part also contain kaolinite, but they are characterized by the presence of two additional groups of clays: (a) very fine grain sized clay particles with irregular shapes forming massive aggregates (Figures 8 and 9) and (b) coarser (up to $1 \mu \mathrm{m}$ ) subidiomorphic tabular to prismatic crystals (Figures 8 and 10). 

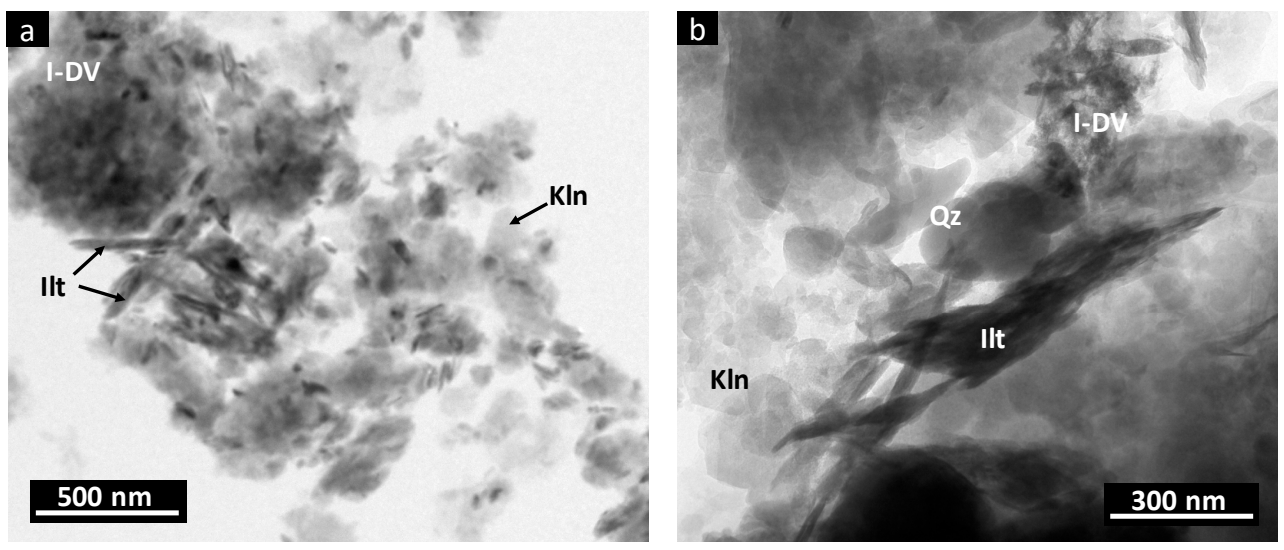

Figure 8. HRTEM pictures of sediments of the central and northern parts of the lake. (a) Textural image of a sediment from the central area; (b) Textural image of a sediment from the north area. Kln: kaolinite, Qz: quartz, I-DV: illite-dioctahedral vermiculite mixed layers, Ilt: illite.
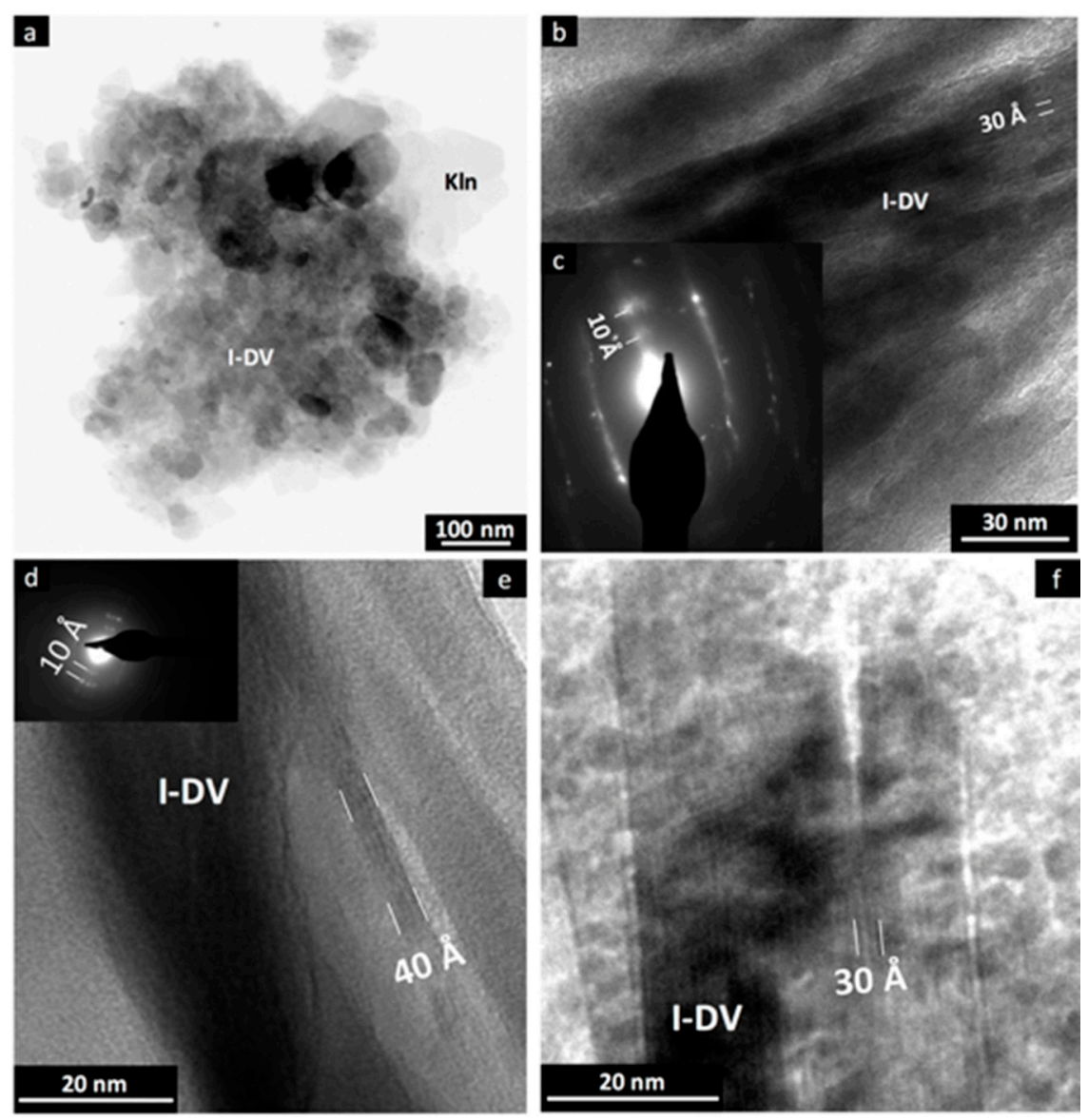

Figure 9. HRTEM pictures showing I-DV details. (a) Textural image of I-DV aggregates. (b,e), and (f) Lattice fringe images of I-DV flakes with some layers of $10 \AA$. (c,d) SAED patterns of I-DV flakes showing $10 \AA$ d-spacing diffraction peaks. Kln: kaolinite, Qz: quartz, I-DV: illite-dioctahedral vermiculite mixed layers. 

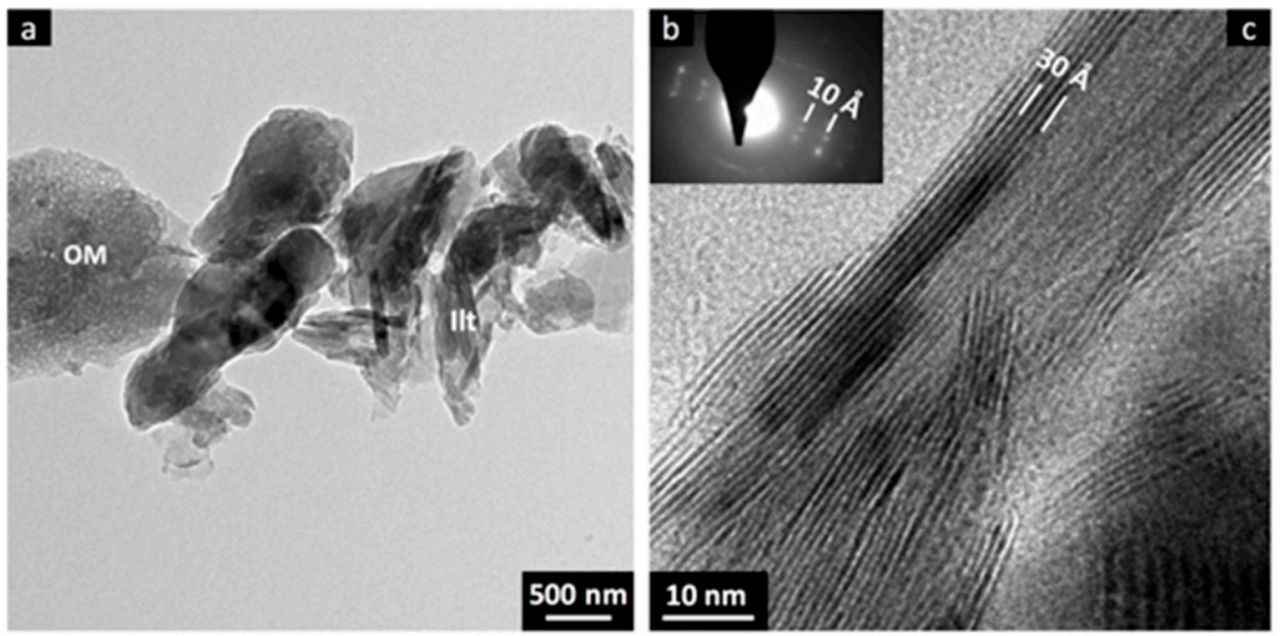

Figure 10. HRTEM images showing details of illite in samples from the central and northern parts of the lake. (a) Textural image of illite in clay aggregates. (b) SAED pattern of illite. (c) HRTEM image of illite showing wide areas of well-defined $10 \AA ̊$ lattice fringes. OM: organic matter, Ilt: illite.

The HRTEM and the selected area electron diffraction (SAED) images of the fine particles show clay flakes where narrow areas with some and discontinuous layers of $10 \AA$ alternate with zones where lattice fringes cannot be observed (Figure 9b-d). The EDX chemical analyses of these particles revealed important contents of tetrahedral Al (>0.50 a.p.f.u.) and small amounts of octahedral Fe (less than 0.18 a.p.f.u.) and $\mathrm{Mg}$ (less than 0.1 a.p.f.u). The layer charge p.f.u. of these minerals oscillates between 0.69 and 0.72 . K was found to be the dominant interlayer cation (0.58-0.64) in the clay composition, indicating a high proportion of illitic layers. According to the high layer charge and high $\mathrm{K}$ content, we relate these minerals with the illite-rich I-DV identified by XRD (Figure 4c). In spite of the presence of the vermiculitic component, this mixed layer shows an octahedral sum very near to 2 a.f.u, which suggests its dioctahedral character.

On the other hand, the SAED and HRTEM images of the tabular subidiomorphic particles (Figure 10a) show wide areas with well-defined $10 \AA$ lattice fringes (Figure 10b,c), suggesting a higher crystallinity than that observed for the I-DV interstratifications. The EDX composition of these crystals has higher $\mathrm{Fe}(0.24-0.31$ a.p.f.u.) and $\mathrm{K}(0.68-0.71$ a.p.f.u.) than that of the I-DV minerals (Table 1). According to these features, we relate these particles with the illite phase identified by XRD in the oriented aggregates of the $<2 \mu \mathrm{m}$ size fraction (Figure 4b).

\section{Discussion}

\subsection{Source Materials: Weathering and Transport}

Sedimentary rocks of Cretaceous and Paleogene ages and the outcrops of acidic vulcanites are the main geological materials in the surrounding areas of the Sochagota Lake (Figure 2) [15], which develop highly weathered soils that are rich in kaolinite and quartz, as expected for soils weathered under a subtropical highland oceanic climate. Quevedo et al. [21] showed that very fine particles of I-DV minerals were formed in the materials draining the Chicamocha River Basin (which also includes the Sochagota Lake Basin) as a consequence of weathering transformations under the high humidity and moderate climate in the Tunja region of Colombia. These materials also feed the Sochagota Lake $[15,28]$.

Yin et al. [33] indicated that the presence of weathering materials that include I-V has been described in different areas, such as in the Appalachians [34], Greenland [35], New Zealand [36], the Adirondacks [37], Virginia [38], Scotland [39], the Southern Taiga [40], and South China [41]. 
High humidity with chemical percolating environments favors the crystallization of clays that include vermiculite layers [42]. Under these temperate climatic conditions, the weathering of micaceous minerals can form vermiculitic mixed layers $[36,38,39,43,44]$. Vanderaveroet et al. $[45,46]$ suggested that the I-V are the result of soil transformations of primary minerals in a temperate climate.

Therefore, climatic conditions in the Sochagota Lake area could produce a partial transformation of primary minerals to kaolinite and vermiculitic minerals as the main clay minerals in the source materials draining the basin, and they favored the formation of small-sized metastable intermediates of I-DV minerals, which were transported to the deposit areas of the basin.

\subsection{Detrital Deposit}

Kaolinite is the prevalent clay from the floodplains of the global Chicamocha River Basin and the Sochagota Lake Basin [25]. In fact, the Sochagota Lake drains to the Chicamocha River $[15,25]$. FESEM and HRTEM images as well as the sharp XRD peaks of the Sochagota Lake sediments clearly indicate that kaolinite is the main detrital mineral of the clay assemblage, especially in the zones of higher hydraulic energy, such as the southern part of the lake characterized by the presence of sediments enriched in coarse grain size fraction due to the prevalence of transport for the fine size fraction enriched in I-DV. We did not find mineral evidence of the reaction of the detrital kaolinite to form K-S mixed layers in the Sochagota Lake sediments. Andrade et al. [6] described this reaction in the soils of Brazilian mangrove forests and indicated the importance of the high salinity of the pore waters and the reducing conditions for this reaction to take place.

Quevedo et al. [25] documented the presence of small amounts of I-DV mixed layers in the floodplain sediments and dam deposits of the Chicamocha River Basin (where waters flow from east to west), suggesting that the small sized particles of I-DV were only deposited in the very low hydraulic energy environments of the basin, whereas sediments deposited under higher hydraulic energy conditions were characterized by the absence of I-DV and high concentrations of bigger-sized kaolinite. A similar process can explain the detrital mineral assemblage distribution in the Sochagota Lake, i.e., higher hydraulic conditions at the south entrance of the lake (Figure 2) avoiding the deposit of the fine grain sized I-DV and producing sediments enriched in kaolinite grains of larger size. When the water flow loses energy in the deepest parts of the Sochagota Lake (center and northern part), the deposit of the fine size particle fractions produces sediments enriched in I-DV.

\subsection{Neoformation of Clay Minerals}

An important clay assemblage change of the Chicamocha River sediments can be observed after receiving the inputs from the Sochagota Lake: illite is absent in the sediments from the eastern upper part of this Chicamocha River Basin located upstream the Sochagota Lake, while traces of illite can be found in the western downstream sediments of the Chicamocha River Basin [25] after including waters from the Sochagota Lake.

This evidence and our results on the distribution of illite and I-DV in the sediments of the Sochagota Lake indicate that the interaction of the hydrothermal waters of the lake, enriched in $\mathrm{K}$ an Fe (see $[15,27,28])$, and the organic matter-rich sediments promoted changes in the chemistry of clays from the sediments studied. In the central and northern parts of the lake, a significant enrichment of I-DV mixed-layer minerals and an Fe-bearing illite can be observed, which is absent in the southern sediments feeding the Sochagota Lake (and in the eastern floodplains of the Chicamocha River Basin before the Sochagota Lake). Illite is present in all samples of the northern and central areas of the Sochagota Lake, but it was not detected in significant amount in the sediments of the south entrance of the lake (neither in the sediments of the upper part of the Chicamocha River Basin, above the lake). Moreover, Fe content is clearly higher in illite (0.24-0.31 a.p.f.u.) than in I-DV (0.11-0.18 a.p.f.u.). The crystallization of illite is a common feature of the Sochagota Lake sediments enriched in organic matter with pyrite, mackinawite and $S^{\circ}[11,24]$. Cifuentes et al. [11,24] have showed 
that the neoformation of the S-bearing phases was produced by sedimentary processes that occurred under the saline and reduced conditions of the sediments $(-150 \mathrm{eV})$, which allowed for the fixation of elements of hydrothermal origin (such as $\mathrm{S}$ and other trace metals, see Cifuentes et al. [24]) enriched in the lake water. These waters are also enriched in hydrothermal potassium. Cuadros et al. [2] indicated that organic matter-rich sediments (such as those of mangroves in tropical environments) can promote quick transformations of clays that favor $\mathrm{K}$ uptake under rapid sedimentation conditions, the percolation of saline waters, the existence of Fe easily mobilized by oxidation-reduction reactions, high activity of organisms, and the existence of precursors able to be transformed into illite. Andrade et al. $[6,8]$ suggested that Fe-illite was formed by the reaction of detrital kaolinite through the formation of mixed-layer minerals in Brazilian mangrove sediments. High concentrations of cations in saline waters and reducing conditions in soils triggered this transformation $[2,6,47]$. However, in the Sochagota Lake sediments we did not find any evidence of the dissolution of kaolinite or its transformation to mixed layers, which excludes kaolinite as the clay mineral precursor to form illite.

However, the mineralogical composition of the sediments as well as the environmental conditions provided by the hydrothermal input to the waters of the lake are consistent with illitization reactions from I-DV mixed layers. I-DV can be an intermediate mineral more reactive under extremely saline conditions than the vermiculitic and smectitic end members [33]. The vermiculite to illite transformation could implicate the exchange of hydrated cations for $\mathrm{K}^{+}$[48-50]. Dietel et al. [23] described I-DV in very low grade metamorphic rocks from Hungary. The characterization of this reported composition suggested that such an interstratified phase could possibly act as an intermediate stage of a steady illite conversion series. Skiba et al. [51] indicated that low hydration energy cations, such as $\mathrm{K}^{+}$or $\mathrm{NH}_{4}{ }^{+}$, can be selectively adsorbed or fixed by vermiculite. Clays saturated with $\mathrm{NH}_{4}{ }^{+}$produced the transformation of dioctahedral vermiculitic layers to form an illite-like phase, which is frequently found in organic matter-rich sediments and soils.

The waters of the lake are enriched in K (more than $280 \mathrm{mg} / \mathrm{L}$ ) of hydrothermal origin [23,24]. Foersters et al. [52] suggested that the increase of potassium concentrations controlled by the hydrochemistry of the paleolake from the Chew Bahir basin was an important factor controlling the authigenic illitization of smectites, which was enhanced by Al-by-Mg substitution in the octahedral sheet. In the Sochagota Lake samples, the presence of a K (0.68-0.71 a.p.f.u.) and $\mathrm{Fe}(0.24-0.31$ a.p.f.u.) rich phase suggests that Fe-bearing illite appears to be the end product of the illitization process. Thus, high $\mathrm{K}$ concentration in the waters of the lake and Fe uptake in the octahedral sheet can promote the illitization of the precursor clays (I-DV). The incorporation of Fe during illitization should be produced by the coupled substitutions of $\mathrm{Al}$ for $\mathrm{Si}$ in the tetrahedral sheet and of $\mathrm{Mg}$ and $\mathrm{Fe}$ for $\mathrm{Al}$ in the octahedral sheet, promoting the incorporation of $\mathrm{K}$ to the interlayer. An I-DV mixed-layer mineral that is progressively richer in $\mathrm{K}$ would be formed as an intermediate in the reaction process. Interstratified clay minerals from the Sochagota lake sediments are dominated by illite-rich phases. Andrade et al. [6] indicated that mixed-layer phases with an intermediate composition of illite layers have a fast reaction rate towards more illitic phases, which can also explain that the relatively high proportion of the illite-rich interstratification of the studied sediments.

\section{Conclusions}

1. Illitization takes place in the Sochagota Lake (Tunja, Colombia). The mineral precursor is detrital mixed-layer I-DV incorporated into the lake by the El Salitre River, which discharges to the south of the lake. The illitization process within the lake is supported by (a) the absence of illite in the sediments of both the El Salitre River, which feeds the lake, and of the Chicamocha River, which receives water from the lake, above the lake mouth, and (b) by the presence of illite both in the lake and in the Chichamocha River below the lake mouth. 
2. TEM-EDS data revealed that neoformed illite has more Fe than I-DV, revealing that the uptaking of Fe played an important role during the illitization process.

3. The chemistry of the lake water, which is enriched in $\mathrm{K}$ and Fe by hydrothermal input, and the reducing conditions generated by the decay of abundant organic matter caused Fe mobilization and the incorporation of $\mathrm{K}$ and Fe into detrital mixed-layer I-DV. This low-temperature illitization process highlights the importance of clays in the uptake of $\mathrm{K}$ from hydrothermal waters in geothermal areas.

Author Contributions: C.P.Q. and G.R.C. conducted field observations and sampling. J.J.-M., R.J.-E., C.P.Q., G.R.C., F.N., and J.C. performed microscopic observations SEM and TEM (mineralogical, textural, chemical analyses) and interpreted the X-ray diffractograms and TOC. All the authors discussed the analytical results and prepared the manuscript. All authors have read and agreed to the published version of the manuscript.

Funding: This work has been financed by the Spanish research project PGC2018-094573-B-I00 from the MCIU-AEI-FEDER. and research group RNM-325 of the Junta de Andalucía (Spain). Our gratitude is also extended to Asociación Universitaria Iberoamericana de Posgrado (AUIP) and the Universidad de Boyacá. Additional thanks to Colombian Research groups Gestión Ambiental COL0005468 and Gestión de Recursos Hídricos COL0005477.

Data Availability Statement: Not applicable.

Acknowledgments: We would like to thank three anonymous reviewers for their suggestions and comments that helped to improve the manuscript.

Conflicts of Interest: The authors declare no conflict of interest. The funders had no role in the design of the study; in the collection, analyses, or interpretation of data; in the writing of the manuscript, or in the decision to publish the results.

\section{References}

1. Baldermann, A.; Warr, L.; Letofsky-Papst, I.; Mavromatis, V. Substantial iron sequestration during green-clay authigenesis in modern deep-sea sediments. Nat. Geosci. 2015, 8, 885-890. [CrossRef]

2. Cuadros, J.; Andrade, G.; Ferreira, T.O.; Partiti, C.S.M.; Cohen, R.; Vidal-Torrado, P. The mangrove reactor: Fast clay transformation and potassium sink. Appl. Clay Sci. 2017, 140, 50-58. [CrossRef]

3. Drief, A.; Martinez-Ruiz, F.; Nieto, F.; Sanchez, N. Transmission electron microscopy evidence for experimental illitization of smectite in K-enriched seawater solution at 50 degrees $\mathrm{C}$ and basic pH. Clays Clay Miner. 2002, 50, 746-756. [CrossRef]

4. Noël, V.; Boye, K.; Kukkadapu, R.K.; Bone, S.; Pacheco, J.S.L.; Cardarelli, E.; Janot, N.; Fendorf, S.; Williams, K.H.; Bargar, J.R. Understanding controls on redox processes in floodplain sediments of the Upper Colorado River Basin. Sci. Total Environ. 2017, 603-604, 663-675. [CrossRef]

5. Kasina, M.; Bock, S.; Wurdemann, H.; Pudlo, D.; Picard, A.; Lichtschlag, A.; Marz, C.; Wagenknecht, L.; Wehrmann, L.M.; Vogt, C.; et al. Mineralogical and geochemical analysis of Fe-phases in drill-cores from the Triassic Stuttgart Formation at $\mathrm{Ketzin}^{\mathrm{CO}_{2}}$ storage site before $\mathrm{CO}_{2}$ arrival. Environ. Earth Sci. 2017, 76, 161. [CrossRef]

6. Andrade, G.R.P.; Cuadros, J.; Partiti, C.M.S.; Cohen, R.; Vidal-Torrado, P. Sequential mineral transformation from kaolinite to Fe-illite in two Brazilian mangrove soils. Geoderma 2018, 309, 84-99. [CrossRef]

7. Deocampo, D.M.; Cuadros, J.; Wing-Dudek, T.; Olives, J.; Amouric, M. Saline lake diagenesis as revealed by coupled mineralogy and geochemistry multiple ultrafine clay phases: Pliocene Olduvai Gorge, Tanzania. Am. J. Sci. 2009, 309, 834-868. [CrossRef]

8. Andrade, G.R.P.; Azevedo, A.C.; Cuadros, J.; Furquim, S.A.C.; Souza, V.S., Jr.; Kiyohara, P.K.; Vidal-Torrado, P. Transformation of kaolinite into smectite and Fe-illite in Brazilian mangrove soils. Soil Sci. Soc. Am. J. 2014, 78, 655-672. [CrossRef]

9. Huggett, J.; Cuadros, J.; Gale, A.S.; Wray, D.; Adetunji, J. Low temperature, authigenic illite and carbonates in a mixed dolomiteclastic lagoonal and pedogenic setting, Spanish Central System, Spain. Appl. Clay Sci. 2016, 132-133, 296-312. [CrossRef]

10. Singer, A.; Stoffers, P. Clay mineral diagenesis in two East African lake sediments. Clay Miner. 1980, 15, 291-307. [CrossRef]

11. Deconinck, J.F.; Strasser, A.; Debrabant, P. Formation of illitic minerals at surface temperatures in Purbeckian sediments (Lower Berriasian, Swiss and French Jura). Clay Miner. 1988, 23, 91-103. [CrossRef]

12. Deconinck, J.F.; Gillot, P.Y.; Steinberg, M.; Strasser, A. Syn-depositional, low temperature illite formation at the Jurassic-Cretaceous boundary (Purbeckian) in the Jura Mountains (Switzerland and France): K/Ar and $\partial^{18}$ O evidence. Bull. Soc. Geol. France 2001, 172, 209-213. [CrossRef]

13. Eberl, D.D.; Srodon, J.; Northrop, H.R. Potassium fixation in smectite by wetting and drying. In Geochemical Processes at Mineral Surfaces; Davis, J.A., Hayes, K.F., Eds.; American Chemical Society: Washington, DC, USA, 1986; pp. $296-326$.

14. Deocampo, D.M. Authigenic clays in lacustrine mudstones. In Paying Attention to Mudstones: Priceless; Egenhoff, S., Ed.; Geological Society of America Special Paper; Geological Society of America: Boulder, CO, USA, 2015; pp. 49-64. [CrossRef] 
15. Cifuentes, G.R.; Jiménez-Millán, J.; Quevedo, C.P.; Jiménez-Espinosa, R. Transformation of S-bearing minerals in organic matter-rich sediments from a saline lake with hydrothermal inputs. Minerals 2020, 10, 525. [CrossRef]

16. Barnes, H.L. Solubilities of ore metals. In Geochemistry of Hydrothermal Ore Deposits, 2nd ed.; John Wiley and Sons: New York, NY, USA, 1997; pp. 404-460.

17. Seward, T.M.; Barnes, H.L. Metal transport by hydrothermal ore fluids. In Geochemistry of Hydrothermal Ore Deposits, 3rd ed.; John Wiley and Sons: New York, NY, USA, 1997; pp. 435-486.

18. Aiuppa, A.; Dongarra, G.; Capasso, G.; Allard, P. Trace elements in the thermal groundwaters of Vulcano Island Sicily. J. Volcanol. Geotherm. Res. 2000, 98, 189-207. [CrossRef]

19. Aiuppa, A.; Federico, C.; Allard, P.; Gurrieri, S.; Valenza, M. Trace metal modeling of groundwater-gas-rock interactions in a volcanic aquifer: Mount Vesuvius, Southern Italy. Chem. Geol. 2005, 216, 289-311. [CrossRef]

20. Pardo, N.; Cepeda, H.; Jaramillo, J.M. The Paipa volcano, Eastern Cordillera of Colombia, South America: Volcanic stratigraphy. Earth Sci. Res. J. 2005, 9, 3-18. Available online: http:/ / www.scielo.org.co/scielo.php?script=sci_arttext\&pid=S1794-6190200500 0100001\&lng=en\&nrm=iso (accessed on 14 May 2021).

21. Kaasalainen, H.; Stefánsson, A.; Giroud, N.; Arnórsson, S. The geochemistry of trace elements in geothermal fluids. Iceland. App. Geochem. 2015, 62, 207-223. [CrossRef]

22. Lanson, B.; Beaufort, D.; Berger, G.; Bauer, A.; Cassagnabere, A.; Meunier, A. Authigenic kaolin and illitic minerals during burial diagenesis of sandstones: A review. Clay Miner. 2002, 37, 1-22. [CrossRef]

23. Dietel, J.; Ufer, K.; Kaufhold, S.; Dohrmann, R. Unusual illite-dioctahedral vermiculite interstratification with Reichweite 2 in clays from northern Hungary. Eur. J. Mineral. 2018, 30, 747-757. [CrossRef]

24. Cifuentes, G.R.; Jiménez-Espinosa, R.; Quevedo, C.P.; Jiménez-Millán, J. El ciclo del azufre en sedimentos de lagos con aportes hidrotermales y antrópicos: El Lago Sochagota (Boyacá-Colombia). Macla 2017, 22, 27-28.

25. Quevedo, C.P.; Jiménez-Millán, J.; Cifuentes, G.R.; Jiménez-Espinosa, R. Clay mineral transformations in anthropic organic matter-rich sediments under saline water environment. Effect on the detrital mineral assemblages in the upper Chicamocha river basin, Colombia. Appl. Clay Sci. 2020, 196, 105576. [CrossRef]

26. Quevedo, C.P.; Jiménez-Millán, J.; Cifuentes, G.R.; Jiménez-Espinosa, R. Electron microscopy evidence of Zn bioauthigenic sulfides formation in polluted organic matter-rich sediments from the Chicamocha River (Boyacá-Colombia). Minerals 2020, 10, 673. [CrossRef]

27. Cifuentes, G.R.; Jiménez-Espinosa, R.; Quevedo, C.P.; Jiménez-Millán, J. Damming induced natural attenuation of hydrothermal waters by runoff freshwater dilution and sediment biogeochemical transformations (Sochagota Lake, Colombia). Water 2021, in press.

28. Cifuentes, G.R.; Jiménez-Millán, J.; Quevedo, C.P.; Gálvez, A.; Castellanos-Rozo, A.; Jiménez-Espinosa, R. Trace element fixation in sediments rich in organic matter from a saline lake in tropical latitude with hydrothermal inputs (Sochagota Lake, Colombia): The role of bacterial communities. Sci. Total Environ. 2021, 762, 143113. [CrossRef]

29. Rye, R.O.; Bethke, P.M.; Wasserman, M.D. The stable isotope geochemistry of acid sulfate alteration. Econ. Geol. 1992, 87, 225-262. [CrossRef]

30. John, D.A.; Lee, R.G.; Breit, G.N.; Dilles, J.H.; Calvert, A.T.; Muffler, L.J.P.; Clynne, M.A. Pleistocene hydrothermal activity on Brokeoff volcano and in the Maidu volcanic center, Lassen Peak area, northeast California: Evolution of magmatic-hydrothermal systems on stratovolcanoes. Geosphere 2019, 15, 946-982. [CrossRef]

31. Nieto, F.; Ortega-Huertas, M.; Peacor, D.R.; Aróstegui, J. Evolution of illite/smectite from early diagenesis through incipient metamorphism in sediments of the Basque-Cantabrian Basin. Clays Clay Miner. 1996, 44, 304-323. [CrossRef]

32. Moore, D.M.; Reynolds, R.C.J. X-ray Diffraction and the Identification and Analysis of Clay Minerals; Oxford University Press: New York, NY, USA, 1997; p. 378.

33. Yin, K.; Honga, H.; Churchman, G.J.; Li, Z.; Fang, Q. Mixed-layer illite-vermiculite as a paleoclimatic indicator in the Pleistocene red soil sediments in Jiujiang, southern China. Palaeogeogr. Palaeoclimatol. Palaeoecol. 2018, 510, 140-151. [CrossRef]

34. Fagel, N.; Robert, C.; Hillaire-Marcel, C. Clay mineral signature of the NW Atlantic boundary undercurrent. Mar. Geol. 1996, 130, 19-28. [CrossRef]

35. Petersen, L.; Rasmussen, K. Mineralogical composition of the clay fraction of two fluvio-glacial sediments from East Greenland. Clay Miner. 1980, 15, 135-145. [CrossRef]

36. Churchman, G.J. Clay minerals formed from micas and chlorites in some New Zealand soils. Clay Miner. 1980, 15, 59-76. [CrossRef]

37. April, R.H.; Hluchy, M.M.; Newton, R.M. The nature of vermiculite in Adirondack soils and till. Clays Clay Miner. 1986, 34, 549-556. [CrossRef]

38. McCartan, L. Geology and Paleontology of the Haynesville Cores Northeastern Virginia Coastal Plain; U.S. Geological Survey: Denver, CO, USA, 1989; p. 1489.

39. Bain, D.C.; Mellor, A.; Wilson, M.J. Nature and origin of an aluminous vermiculitic weathering product in acid soils from upland catchments in Scotland. Clay Miner. 1990, 25, 467-475. [CrossRef]

40. Bonifacio, E.; Falsone, G.; Simonov, G.; Sokolova, T.; Tolpeshta, I. Pedogenic processes and clay transformations in bisequal soils of the Southern Taiga zone. Geoderma 2009, 149, 66-75. [CrossRef] 
41. Yin, K.; Hong, H.; Churchman, G.J.; Li, R.; Li, Z.; Wang, C.; Han, W. Hydroxyinterlayered vermiculite genesis in Jiujiang late-Pleistocene red earth sediments and significance to climate. Appl. Clay Sci. 2013, 74, 20-27. [CrossRef]

42. Hong, H.; Churchman, G.J.; Yin, K.; Li, R.; Li, Z. Randomly interstratified illite-vermiculite from weathering of illite in red earth sediments in Xuancheng, southeastern China. Geoderma 2014, 214, 42-49. [CrossRef]

43. Berry, R.W.; Johns, W. Mineralogy of the claysize fractions of some North Atlantic Arctic Ocean bottom current. Geol. Soc. Am. Bull. 1966, 77, 183-196. [CrossRef]

44. Srodon, J. Nature of mixed-layer clays and mechanisms of their formation and alteration. Annu. Rev. Earth Planet. Sci. 1999, 27, 19-53. [CrossRef]

45. Vanderaveroet, P.; Averbuch, O.; Deconinck, J.F.; Chamley, H. A record of glacial/interglacial alternations in Pleistocene sediments off New Jersey expressed by clay mineral, grain-size and magnetic susceptibility data. Mar. Geol. 1999, 159, 79-92. [CrossRef]

46. Vanderaveroet, P.; Bout-Roumazeilles, V.; Fagel, N.; Chamley, H.; Deconinck, J.F. Significance of random illite/vermiculite mixed-layers in Pleistocene sediments of the northwestern Atlantic Ocean. Clay Miner. 2000, 35, 679-691. [CrossRef]

47. Vilhena, M.P.S.P.; Costa, M.L.; Berrêdo, J.F. Continental and marine contributions to formation of mangrove sediments in an eastern Amazonian mudplain: The case of Marapanin estuary. J. S. Am. Earth Sci. 2010, 79, 427-438. [CrossRef]

48. Barnishel, R.I.; Bertsch, P.M. Chlorites and hydroxy-interlayered vermiculite and smectite. In Minerals in Soil Environments, 2nd ed.; Dixon, J.B., Weed, S.B., Eds.; Soil Science Society of America: Madison, WN, USA, 1989.

49. Meunier, A. Soil hydroxy-interlayered minerals: A re-interpretation of their crystallochemical properties. Clays Clay Miner. 2007, 55, 380-388. [CrossRef]

50. Velde, B.; Meunier, A. The Origin of Clay Minerals in Soils and Weathered Rocks; Springer: Berlin/Heidelberg, Germany, 2008.

51. Skiba, M.; Skiba, S.; Derkowski, A.; Maj-Szeliga, K.; Dziubińsk, B. Formation of $\mathrm{NH}_{4}$-Illite-like phase at the expense of dioctahedral vermiculite in soil and diagenetic environments-An experimental approach. Clays Clay Miner. 2018, 66, 74-85. [CrossRef]

52. Foerster, V.; Deocampo, D.; Asrat, A.; Günter, C.; Junginger, A.; Kraemer, K.H.; Stroncik, N.; Trauth, M. Towards an understanding of climate proxy formation in the Chew Bahir basin, southern Ethiopian Rift. Palaeogeogr. Palaeoclimatol. Palaeoecol. $2018,501$. [CrossRef] 